\title{
Electrophoretic, Sedimentation and Diffusion Behaviour of Crystalline Neuraminidase from Vibrio cholerae
}

\author{
By J. PYE \\ The Walter and Eliza Hall Institute of Medical Research, \\ Royal Melbourne Hospital Post Office, Victoria, Australia \\ AND C. C. CURTAIN \\ Baker Medical Research Institute, Alfred Hospital, \\ Melbourne, Victoria, Australia
}

(Received 21 October 1960)

\section{SUMMARY}

Crystalline neuraminidase prepared from Vibrio cholerae culture fluids by Ada, French \& Lind (1961) was examined by moving boundary electrophoresis, analytical ultracentrifugation and diffusion. The various corresponding physical constants were obtained. The results indicated that, within the limits of the methods used, the crystalline protein was enzyme and was homogeneous.

\section{METHODS}

Neuraminidase. Crystalline neuraminidase (a pool of three batches) was supplied by Dr G. L. Ada. Because of the scarcity of the purified enzyme, all physical measurements were carried out on this pool. The enzyme was submitted first to diffusion analysis, then to electrophoresis and finally to sedimentation in the ultracentrifuge. After each examination, the enzyme was dialysed against distilled water and concentrated by sublimation of water from the frozen state in vacuo. In some cases, a considerable time elapsed between experiments and during these periods the dissolved enzyme was stored at $-20^{\circ}$.

Buffers. For electrophoresis: (1) sodium veronal ( $\mathrm{pH} \mathrm{8.5,} \mathrm{0.012} \mathrm{M}$ ) +sodium

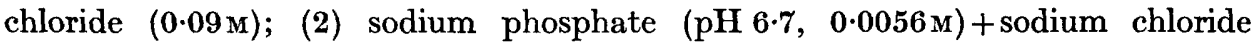
$(0.09 \mathrm{M}) ;(3)$ sodium acetate $(\mathrm{pH} 5 \cdot 1,0.0145 \mathrm{M})+$ sodium chloride $(0.09 \mathrm{M})$. The ionic strength of each of these buffers is $0 \cdot 1$.

For sedimentation: (4) sodium veronal $(\mathrm{pH} 8 \cdot 5,0 \cdot 01 \mathrm{M})+$ sodium chloride $(0 \cdot 1 \mathrm{M})$;

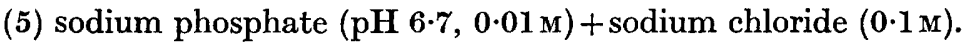

For diffusion: the sodium phosphate buffer (no. 5) used for sedimentation.

Moving boundary electrophoresis. This was carried out at $4^{\circ}$ in a Tiselius type equipment with cylindrical lens schlieren optical system. A $2 \mathrm{ml}$. optical cell was used. The assembly was closed on the anode side. At the conclusion of each run the cell was closed and the contents of the two limbs and the base removed separately for biological assay of enzyme activity (French \& Ada, 1959). We are indebted to Dr P. E. Lind for carrying out these estimations. Mobilities of the boundaries observed and of the enzyme activities were calculated for the descending limb by using the conductivities of the supernatant buffer solutions. 
Ultracentrifugation. An air-driven Beams-Pickels type of centrifuge with a cylindrical lens schlieren optical system was used at a rotor speed of $800 \mathrm{rev} . / \mathrm{sec}$. and a temperature of about $20^{\circ}$.

Diffusion. The diffusion experiment was carried out at $1.5^{\circ}$ in a $2 \mathrm{ml}$. cell in the Perkin-Elmer Model 38 A electrophoresis apparatus with the phase-plate gradient optical system of Moore \& Opperman (1956). The cell bath of this instrument was maintained to $\pm 0.02^{\circ}$ by circulating water from a refrigerated tank (built by Cordley \& Hayes, New York, for the Perkin-Elmer Corporation).

\section{RESULTS}

Electrophoresis. The electrophoretic patterns observed at $\mathrm{pH} 6 \cdot 7,8 \cdot 5$ and $5 \cdot 1$ are shown in Pl. 1, fig. 1(a), (b), (c). In each case a single peak was observed which migrated towards the anode. In the first two analyses the peaks were asymmetrical. During dialysis against the $\mathrm{pH} 5 \cdot 1$ buffer, a slight precipitate formed and this was removed by centrifugation. The peak subsequently observed during electrophoresis at $\mathrm{pH} 5 \cdot 1$ was almost symmetrical. The mobilities of these boundaries and of the enzyme activities are given in Table 1.

Table 1. Electrophoretic mobilities of Vibrio cholerae neuraminidase at various $\mathrm{pH}$ values

$\begin{array}{ccccc}\text { pH value: } & & 6 \cdot 7 & 8 \cdot 5 & 5 \cdot 1 \\ \text { Mobilities }\left(10^{-5} \mathrm{~cm}^{2} \text { sec. }^{-1} \text { volt }\right. & & & \\ & \text { Protein boundary: } & 3 \cdot 8 & 3 \cdot 9 & 2 \cdot 1 \\ & \text { Enzyme activity: } & 3 \cdot 8 & 4 \cdot 1 & 2 \cdot 1\end{array}$

Sedimentation. The enzyme sedimented as a single symmetrical boundary at pH 6.7 and 8.5 (see Pl. 1, fig. $2(a),(b),(c)$ and fig. $3(a),(b),(c))$. At pH 6.7, the sedimentation was observed at concentrations of $0.9 \%, 0.6 \%$ and $0.3 \%(\mathrm{w} / \mathrm{v})$. There was no apparent dependence of sedimentation coefficient on protein concentration within the accuracy of the methods used. At $\mathrm{pH} 6.7, s_{20}$ was $5.5 \mathrm{~S}$; at $\mathrm{pH} 8.5$, $5 \cdot 3 \mathrm{~S}$.

Diffusion. At a concentration of $0 \cdot 72 \%(\mathrm{w} / \mathrm{v})$ and $\mathrm{pH} 6 \cdot 7$ the Vibrio cholerae neuraminidase gave a value for $\mathrm{D}_{20}$ of $5.5 \times 10^{-7} \mathrm{~cm} .{ }^{2} \mathrm{sec} .^{-1}$.

\section{DISCUSSION}

The results of the sedimentation and electrophoresis measurements left little doubt that we were dealing with a protein preparation which was substantially homogeneous, at least within the limits of the methods used. The small amount of material insoluble at pH 5.1 might have been denatured or aggregated neuraminidase and as such could have been responsible for the asymmetry of the electrophoretic boundaries at $\mathrm{pH} 6 \cdot 7$ and $8 \cdot 5$. The agreement between the electrophoretic mobilities of the enzymically active material and the protein boundaries at three $\mathrm{pH}$ values suggested that the crystalline protein was in fact neuraminidase. This was supported by the finding that a single peak with constant specific activity was obtained during chromatography of the material on hydroxy-apatite (Ada et al. 1961). No attempt was made to correlate the sedimenting boundaries with enzymic activity. The mobility values indicated that the isoelectric point of neuraminidase 

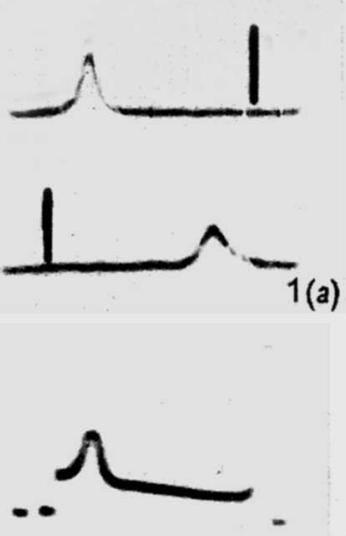

2(a)

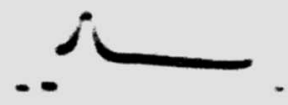

$3(a)$
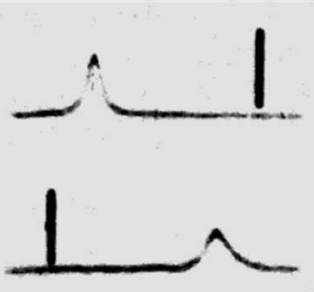

(b)

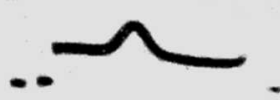

(b)

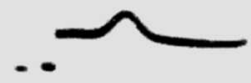

(b)

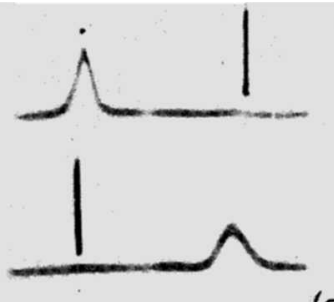

(c)

(c)

(c) 
was below $\mathrm{pH} 5 \cdot 1$. The instability of the enzyme at lower $\mathrm{pH}$ values (Ada et al. 1961) precluded any attempt to determine the actual value.

If a partial specific volume of 0.75 be assumed, calculation from the sedimentation and diffusion coefficients yields a molecular weight of 90,000 and a frictional ratio $\left(f / f_{0}\right)$ of $1 \cdot 2_{0}$. These results were obtained with a phosphate buffer at $\mathrm{pH} 6 \cdot 7$; the sedimentation coefficient in veronal buffer at $\mathrm{pH} 8.5$ was not significantly different. Schramm \& Mohr (1959) obtained a sedimentation coefficient of 1.3S in veronal buffer at $\mathrm{pH} 8.5$ in presence of potassium cyanide for a neuraminidase isolated from filtrates of Vibrio cholerae cultures; they found evidence of aggregation in other media (unspecified). There are at present insufficient data to account for the differences between the two enzyme preparations.

We are grateful to Mr H. F. Holden who carried out the sedimentation runs and to Mr I. J. O'Donnell for the use of a Cambridge Universal Measuring Machine. One of us (J.P.) was supported by the National Health and Medical Research Council, Canberra, Australia.

\section{REFERENCES}

Ada, G. L., French, E. L. \& Lind, P. E. (1961). Purification and properties of neuraminidase from Vibrio cholerae. J. gen. Microbiol. 24, 409.

French, E. L. \& ADA, G. L. (1959). Stimulation of the production of neuraminidase in Vibrio cholerae cultures by $N$-acetylneuraminic acid and sialyl lactose. J. gen. Microbiol. 21, 550.

Moore, D. H. \& Opperman, K. (1956). Adaptation of combined interferometric and phaseplate gradient optics to electrophoresis. Biochim. biophys. Acta, 22, 136.

Schramm, G. \& Mohr, E. (1959). Purification of neuraminidase from Vibrio cholerae. Nature, Lond. 183, 1677.

\section{EXPLANATION OF PLATE}

Fig. 1. Moving boundary electrophoresis of Vibrio cholerae neuraminidase. (a) pH $6 \cdot 7 ; 5 \cdot 8$ volt $\mathrm{cm}^{-1}$ for $189 \mathrm{~min}$. (b) $\mathrm{pH} 8 \cdot 5 ; 5 \cdot 7$ volt $\mathrm{cm} .^{-1}$ for $177 \mathrm{~min}$. (c) $\mathrm{pH} 5 \cdot 1 ; 5.6$ volt $\mathrm{cm}^{-1}$ for $327 \mathrm{~min}$. In each case the upper and lower patterns represent the ascending and descending limbs, respectively. The vertical line indicates the initial position of the boundary.

Fig. 2. Sedimentation of Vibrio cholerae neuraminidase. $0.9 \%(\mathrm{w} / \mathrm{v})$ at $\mathrm{pH} 6 \cdot 7$. Speed of rotor, $800 \mathrm{rev} . / \mathrm{sec}$. From left to right, exposures at $43(a)$, at $111(b)$ and at $164 \mathrm{~min}$. $(c)$ after reaching full speed.

Fig. 3. Sedimentation of Vibrio cholerae neuraminidase. $0 \cdot 8 \%(\mathrm{w} / \mathrm{v})$ at $\mathrm{pH} 8 \cdot 5$. Speed of rotor $800 \mathrm{rev} . / \mathrm{sec}$. From left to right, exposures at $37(a)$, at $97(b)$ and at $157 \mathrm{~min}$. $(c)$ after reaching full speed. In every case sedimentation occurs from left to right. 